\title{
Childhood Religion, Minority Setting
}

\author{
Childhood Religion - "Lived" Religion
}

The displaced Karelian Orthodox women's present-day religion was a product of history: past practices and experiences. In this chapter, I approach the women's habitus by tracing their religious trajectories from the interview material. I focus on some of the contexts that had profoundly influenced their religious practice, starting with childhood. In the sociology of religion, the impact of the childhood family on the development of adulthood religiosity is often considered crucial (e.g., Hunt 2007, 614-615; McGuire 1997, 53-56). I treat the women's descriptions of childhood religion as evidence of their experiences, for the moment bracketing the possible impact of the interview situation on their interpretations.

The interviewees had been socialized into the Orthodox Christian religion since early childhood. In their childhood family lives, they stressed, religion had played a central role. Those informants who had spent most of their childhood in Karelia often pointed out the self-evident status of Orthodoxy in the overall environment. In this vein, Lyyli noted: "You couldn't think anything special about Orthodoxy; it was a part of life. There was no Lutheranism." Also those women whose childhood coincided with the period of resettlement, however, usually stated that Orthodoxy had had a strong presence within their homes, even if, elsewhere, Lutheranism was the norm. ${ }^{1}$

The women described the status of religion in their childhood environments by connecting it with the overall way of life. Religion was "everyday life," "a way of life," or "part of all action." To signal particular commitment to religion, they might even speak of the "living" of religion. Hilja, for example, remembered her grandmother's religiosity by noting how "she lived her religion so deeply." And Elvi stated, of her grandparents, how "religion lived strongly in their lives." As evidence of the unity of religion and life, the women provided examples testifying to the presence of Orthodoxy in their childhood surroundings: customs, norms, forms of conduct, and so on. According to them, daily religious

1 Maija-Liisa, who had an Orthodox father and a Lutheran mother, was an exception on this point. According to her, the domestic religious life of her childhood family was more tilted towards Lutheranism than Orthodoxy. 
practices were unfailingly observed. Religion, moreover, also functioned as an overarching moral guideline. As the foundation of values and beliefs, it formed the background against which life as such and different life situations were interpreted.

In Bourdieuan vocabulary, doxa is a relationship constituted between the individual and the social world when the individual comes to embody a particular social position inadvertently, commonly through primary socialization (Bourdieu 199ob, 67-68; see also Deer 2008a, 119-120). It describes the unquestioned and taken-for-granted part of the individual's knowledge of the social world. The women's accounts summarized above closely resemble Bourdieu's description of doxa. They describe how religion had formed a self-evident element of the interviewees' childhood surroundings. It was ever-present; moreover, this presence was not challenged or even taken under conscious consideration. Religion was so ubiquitous that it was "nothing special."

Another issue that the women often addressed when speaking of their childhood religion was the process of religious socialization. It was common for them to stress how religion had not been explicitly taught or learned. Kirsti, for instance, described the adoption of "an Orthodox state of mind" as kind of osmosis. According to her, religion "was transferred through skin contact, through the surrounding atmosphere. Not everything in it can be read; a part is transferred to people unbeknownst to them." With these kinds of accounts, the women emphasized that their Orthodox practice was not something adopted through conscious study. Rather, it had been acquired through growing up in an Orthodox environment.

Overall, in describing their religiosity, the interviewees made use of corporeal metaphors. For example, they might note that their religion was "innate" or "in their genes," or that they were "Orthodox by birth." A related expression employed by the women was that they had received Orthodoxy "in their mother's milk." What all these descriptions imply is that their religion had originated before or soon after their birth. Moreover, the informants could also suggest that religion was ingrained in their bodies, an essential and irremovable part of their lives and selves. It resided "in the back of the head," was "part of the skin," or was "stuck to the scalp."

Raili: Let's say that I've been Orthodox already since before birth. It's (...) almost like a gene; it's in you already. So, it feels so hard to imagine, I cannot even imagine being Lutheran. That I'd change to Lutheranism. I think that religion has to, it has to start with the child. That you 
experience having an Orthodox God, even if God is the same for everyone but still...

In the account above, Raili notes that her Orthodoxy predates her birth, comparing it "almost" to a gene. With this expression, she illustrates that Orthodoxy is fundamental to her very being. Raili connects this state of affairs to her having experienced an "Orthodox God" in childhood. Generally speaking, it was common for the women to tie their embodied experiences of religion to their childhood religious socialization. Through corporeal metaphors, they described the enduring effects of their childhood religion in their present-day lives.

Raili's description, in many ways, comes close to Bourdieu's understanding of native membership as a mode of partaking in a field. According to Bourdieu (199ob, 67), the individual's belief in the game of a particular field is the highest when he or she is "born into the game." The statement refers to the effects of primary socialization. In any sufficiently stable environment, primary socialization results in a doxic relationship with the surrounding world. It produces a worldview that, lacking options, appears self-evident and natural. The interviewees' accounts of their religious socialization, on the whole, can be read as descriptions of the process of being born into a game. They imply that the women had adopted a religious way of life automatically. They also depict childhood religion as a taken-for-granted part of life, thus suggesting an embodied experience of harmony between native habitus and native field. Furthermore, the corporeal metaphors used by the informants to describe their present-day religious practice can be seen to depict the continuing influence of this native layer of their habitus. The metaphors convey an experience of being in possession of deeply ingrained, embodied knowledge concerning religion that was hard to shake off.

The women also approached the native part of their present-day habitus through accounts that explicitly grounded their present religious practice in their childhood. Thus, Esteri, among others, insinuated that the experience of religion as a self-evident aspect of life, realized through habitual customs, had characterized her religiosity since childhood.

Helena: I'd like to start with a general question: How would you describe yourself as an Orthodox woman? How might you describe it?

Esteri: Well, we were Orthodox at home... Our daily rhythm went just like my parents had taught me. In the morning, the first thing was to say a 
prayer, when you had a wash. You crossed your eyes, that is, you made the sign of the cross. Always with the mealtime prayer and after you finished eating, you had to make the sign of the cross when leaving the table. ${ }^{2}$ It was like thanks to Orthodoxy. (...) It stuck, the way of the parents. And it has followed me; I've observed [these customs] down to this day.

According to Bourdieu (199ob, 53-54, 6o-61), habitus functions by transforming experiences into dispositions. In any situation, the individual's habitus guides his or her reactions based on his or her past experiences of such situations. This pattern creates a built-in tendency toward stability, and a partiality towards early experiences. In Esteri's case, for instance, every subsequent morning prayer was further support for her practical sense that the childhood custom truly was the proper way to start her day.

Judging from examples such as the one above, the women's present-day religiosity remained strongly shaped by their childhood socialization into religion. Often, the interviewees also described their present practices with phrases suggesting a doxic relationship towards the social world. They might note, for example, how morning and evening prayers came "naturally" to them. However, as I have already established, the women's present-day religious activity did not simply replicate childhood religion. On the contrary, many of their childhood customs were no longer part of their lives. The evolution of their practice points to changes in their embodied knowledge concerning the social world.

Memory material always reflects the present significance of the past to the individual in question. The interviewees' memories of childhood religion, produced in the interview context, carried both nostalgic and normative connotations. Through describing childhood religion, the women also outlined their view of proper religiosity. In their parlance, the expression "to live religion" referred to the ideal way of practicing Orthodoxy. When religion was lived, it was so fundamental to the individual's interactions with the social world that everything became part of religious practice. This type of practice acts out Bourdieu's concept of doxa in a profound sense. However, the women virtually never spoke of their own religiosity as the "living" of religion. Instead, they often admitted that their religious practice fell short of that of their devout parents or grandparents. In a more or less outright way, they lamented that the confluence of religion and life was not an easily attained state. One explanation as to why the "living of religion," as a modality of religious practice, was so hard for the women to attain is that their relationship towards religion was no

2 The custom of washing one's face and hands before saying one's prayers in the morning and before mealtimes was common in pre-Second World War Karelia (see e.g., Keinänen 2010a, 125, 129-131; Pentikäinen 1971, 149, 154). 
longer simply doxic in character. During the course of their lives, that is to say, their habitus had come to include other layers beside the native one.

\section{Embodied Minority Experiences}

I met Faina at an Orthodox lay association meeting where she was one of the women in charge of the coffee service. She enthusiastically agreed to my request to interview her, and we settled on a date then and there. When I arrived at her home, a one-bedroom apartment in an Art Nouveau style building in Helsinki, the first thing that caught my attention was a large map of Suojärvi on the wall by the front door. Faina was eight years old when the Winter War began, and her family had been evacuated from Suojärvi to Alahärmä, in South Ostrobothnia. Unlike many Karelians, the family did not move back east during the Continuation War.

For Faina and her siblings, living as Orthodox Karelians in Alahärmä had not been easy. The local children had mocked both their dialect and their religion, by, for instance, calling them "Russians." Several summers in a row, Faina had participated in camps and festivals organized by the Orthodox Youth Association. "It was the high point of those years, when we got rid of Ostrobothians, and got to be with our own people," she exclaimed. "It reinforced our religion, too."

Faina left home at a young age and moved to the capital, Helsinki. She worked first as a nanny in an upper-class family and later at a hospital, where she remained for almost 50 years. She emphasized that she had never disguised her religious affiliation at work. Rather, she had even obtained special permission from the head of her ward to end her shift early to attend the Easter Vigil. That is to say, Faina had not been mistreated at work because of her background. The same was not quite the case at home, though, for her father-in-law had been heavily prejudiced against Karelians.

Faina's husband was a Lutheran from a village in southwestern Finland, where many had had to give up some of their land to create plots for evacuees. "We were all just damned Karelians to him," as Faina described her father-in-law's attitude towards displaced Karelians. Nevertheless, neither he nor the rest of her husband's family had been against her Orthodox religion per se: "They never demanded that I convert. That was never the case. Many converted because it was the only way to get along [with in-laws]." She paused for a moment, and continued: "Well. Even if they had tried, they could never have forced me to leave the Church." 
In pre-war Karelia, some of the displaced Karelian Orthodox women had had virtually no contact with Lutherans, while others had lived in villages with a Lutheran presence. In either case, the evacuations from Karelia changed their religious environs permanently. The situation of the Finnish Orthodox community during the first post-war decade was characterized by material deprivation and the reservations of the majority population. Depending on the informant's age, this period coincided either with her childhood or young adulthood. While the family constitutes the primary source of socialization in early childhood, after reaching school-age children begin to have more and more contacts outside the familial sphere. Accordingly, the women's accounts reveal their growing awareness of the Lutheran mainstream culture during this period in their lives.

The interviewees' overall evaluations concerning the locals' treatment of Orthodox evacuees ranged from "open-hearted" and "respectful" to "disdainful" and "cruel." The appraisals reflect differences in both the women's experiences and their reactions to the interview situation. There was actual geographical variation in how well the evacuees fit into receiving communities. In their accounts, moreover, some informants emphasized positive incidents and others negative ones. Certain story-lines, however, recurred throughout the material.

In post-war Finland, the Orthodox Church and its members were often called ryssä, a pejorative for Russian. According to Heli Kaarina Kananen (2010, 84-91), ryssä-calling was an activity with which the local population strived to control the Orthodox refugees and to establish a social hierarchy that relegated them to a second-class status. In the interviews, the women often spontaneously recounted experiences of such name-calling, usually dating back to their school years. A few informants, for their part, wanted to clarify that they, unlike others, had not been called ryssä. Nevertheless, that practically all the women engaged with the theme demonstrates its importance. It was part of the collective experience of the Orthodox of their generation to have been called names by others.

When describing the post-war context, the interviewees also spoke of the overall mood of the Orthodox population. The women noted how, at the time, people did not necessarily show their Orthodoxy, and how they were sometimes downright ashamed of their religion. While some, similar to Faina, emphasized that they had not hidden their religion, others admitted that they had been affected by this general atmosphere. Martta, for instance, explained: "We had this belief that everyone else is better than us Orthodox, who are down-to-earth and like that. (...) We had to be silent about that ryssä faith. That's what pushed us down." Moreover, the informants might also describe how they had learned to suppress their Orthodox practices to suit the various environments in which they represented the minority, particularly at school. 
Toini: [The making of the sign of the cross] became less frequent when we were in evacuation. Perhaps there was some avoidance there, some shyness. When we stayed at a farmhouse living-room as evacuees. It was left to be done in secret; we like shunned a bit from making the sign of the cross. Just like at school. (...) It was something, not a thing to be ashamed of, but still we didn't want to show that we did it.

Toini's account describes the shyness and embarrassment accompanying the practice of making the sign of the cross publicly in the post-evacuation context. These kinds of bodily emotions often result from contradictions within habitus. They arise from the sense of being deeply involved in something that, in the eyes of others, places you squarely on the wrong side of the "magical frontier between the dominant and the dominated" (Bourdieu 2001, 38; see also Probyn 2004, 239; Scheer 2012, 204-209). In Toini's case, the contradiction was between the practical sense urging her to make the sign of the cross during, for instance, collective prayers at school, and the practical sense advising her that making the sign of the cross marginalized her within the community. All in all, Toini's account is an example of how the attention that Orthodox practices drew from the Lutheran population took root within the bodies of the informants. Her description does not depict the sign of the cross as doxa, as an unquestioned part of everyday life. Rather, it provides evidence of how experiences of practicing Orthodoxy amongst Lutherans had affected the women's dispositions, adding layers to their habitus.

In his theory, Bourdieu stresses the relative stability of habitus (Bourdieu 199ob, 53-54; Bourdieu and Wacquant 1992, 133). Toini's account, however, shows that in the exceptional circumstances of the evacuations, some women's dispositions with respect to some of their religious activities evolved rapidly. When the surrounding environment is dramatically changed, new experiences cannot necessarily be interpreted in the light of earlier ones, in which case they can have more drastic effects on habitus. One central factor in the flexibility (or rigidity) of habitus is the amount of past experiences it has heretofore absorbed. For instance, as regards the Orthodox evacuees, previous research suggests that older evacuees commonly stayed more true to their pre-war customs in post-war Finland than younger ones (Heikkinen 1989, $326-336)$.

Besides experiences of being singled out from the Lutheran majority, the women's memories of the post-war years also included experiences of affinity among the Orthodox. Several informants in addition to Faina (in the vignette above) mentioned Orthodox Youth Association camps and festivals as particularly impressive experiences. Lempi, for example, reminisced: "There might be 
even a couple hundred of us at one camp. (...) Maybe the greatest experience there for many was that we can be many too. That we aren't just lonely recluses (laughs)." Furthermore, the women had also participated in fundraising projects aimed at setting up new churches and chapels, which demonstrated the collective strength of the Orthodox community and reinforced the self-esteem of its members.

Since the Second World War period, the status of Orthodox Christianity in Finnish society has transformed from a stigmatized minority denomination to a respected minority denomination (e.g., Martikainen and Laitila 2014, 164, 172). The women of my study described the present situation of the Orthodox Church as much improved from earlier times, speaking of this change with relieved and amazed tones. Vieno, for instance, wondered: "You wouldn't have believed it! Everyone said that the Orthodox faith would die altogether. Today we're really at the top." Regardless, the interviewees might also imply that the extent of the change had left them baffled. The current popularity of the Church felt "alien," "over the top," even "slightly embarrassing." I interpret these comments to testify to the profound impact that the first post-war decades had made on the women. Habitus is first formed during childhood and youth, and early experiences commonly have a lifelong influence on the individual. As young people, whose socialization to the Orthodox religion was still under way, the women's habitus had been deeply affected by the marginalized status of Orthodoxy during the post-war years. Moreover, in spite of the changed relations between Orthodox and Lutheran Finns since those times, these original minority experiences continued to affect their dispositions even today. In some ways, their habitus remained geared to another kind of an environment.

The informants who admitted to having felt ashamed of their Orthodox practices before usually stressed that, nowadays, the situation was different. At present, they were proud of their Orthodoxy. This change from shame to pride parallels the evolution of the status of Orthodoxy in Finland. Both embodied emotions, however, can be seen to reflect the same state of affairs: namely, the rootedness of the minority status in the women's habitus. They stem from the interviewees' embodied knowledge of distinction and difference with respect to the Lutheran other.

Helena: In what kinds of situations do you make the sign of the cross these days?

Vieno: Of course at church and at these Orthodox functions at home. Still, at this age, what happens is, or maybe it's a common trend, that when you go out to eat at a restaurant you just make it quickly, [then] 
start to eat. Inconspicuously. However, somehow it feels that you can't start eating without [making it].

Helena: Oh, has this started recently, this restaurant thing?

Vieno: Well, not that recently, but as I got older anyway. And the grandchildren, though some of them may roll their eyes a bit, they're used to grandma doing it, yes.

This account constitutes a good example of the ways in which living in a Lutheran-dominated environment had molded the interviewees' habitus. In the excerpt, Vieno points out several subtle impulses affecting her making the sign of the cross in public. On the one hand, she notes that, as she becomes older, she has become more self-conscious about crossing herself at restaurants. This statement suggests a change in habitus due to long-term exposure to Lutheran culture, to nearly a lifetime of living amid Lutherans. On the other hand, Vieno also explains that, nevertheless, she "can't start eating without" doing the gesture, thus acknowledging the continuing influence of the dispositions she had developed in early childhood.

Additionally, Vieno's account also illustrates how the women sometimes did religion, more or less intentionally, in relation to the Lutheran other. In postwar Finland, actions such as making the sign of the cross publicly became statements of minority identity. In present-day Finland, they still are that, to some extent. This kind of a situation can instill a conscious dimension into practice (see Adkins 2003, 26-27; Akram 2013, 57). Vieno, above, recognizes that her Lutheran grandchildren take note of her making the sign of the cross before eating, and seems pleased that she has familiarized them with the custom. In other words: even as Vieno followed the dispositions ingrained in her habitus, she was also performing her Orthodoxy for the benefit of her grandchildren.

\section{Orthodox Christianity versus Evangelical Lutheranism}

So far in this chapter, I have investigated the conditions of production of the interviewees' habitus through a reconstruction of two distinct phases in their religious trajectories. As part of the discussion, I compared their childhood descriptions with Bourdieu's notion of doxa. Their post-war accounts, in contrast, can be seen to depict a situation in which religion has, to some extent, lost its doxic status. These accounts position Orthodoxy as secondary to the Lutheran version of Christianity, and describe the women's embodied reactions to this new hierarchy. 
According to Bourdieu, the struggle between orthodoxy and heterodoxy constitutes the opposite of doxa. It informs behavior within any field in which different social actors have developed parallel interpretations of the world and compete over discursive dominance (Calhoun 1993, 79-8o). In such situations, the individual's embodied knowledge concerning the social world is challenged by his or her awareness of the existence of alternatives. The individual comes to renounce, in part, his or her doxic attitude towards the social world, and to adopt an orthodox (the dominant discursive position) or heterodox (any contending position) attitude instead.

For the greater part of their lives, the interviewees had practiced their religion in an environment characterized by the existence of alternative interpretations of Christianity. Moreover, the position they occupied within the religious field was a heterodox one, compared to the orthodox Lutheran discourse. One possible expression of a heterodox attitude towards the social world is habitual reflection: an ability to contemplate, in a routine fashion, on the various experienced and articulated differences in one's social surroundings (Adkins 2003, 34-35; see also Bourdieu 2000, 163). The women's capacity and tendency to make comparisons between Orthodox Christianity and Evangelical Lutheranism can be regarded as an example of such reflection. It was a feature of their habitus, and an effect of their history as religious practitioners in Lutheran-dominated Finland.

The juxtaposition between Orthodoxy and Lutheranism was present in the interviews on many levels. My questions repeatedly positioned the women as representatives of Orthodoxy. I also explicitly asked them about the differences between Orthodoxy and Lutheranism. Furthermore, it was important to most informants to learn of my religious affiliation. They were thus conscious of producing their accounts to a Lutheran audience. Nevertheless, my overall impression was that the interviewees did not need to be coaxed into making comparisons between Orthodoxy and Lutheranism. On the contrary, such comparisons came easily to them.

In the interviews, it was common for the women to describe Orthodox Christianity by opposing it with Lutheranism. The women might, for instance, contrast the age and stability of Orthodox practices and teachings with what they viewed as Lutheran instability. Based on this difference, they deemed Orthodox traditions more authentic compared to Lutheran ones. ${ }^{3}$ Senja, for example, noted: "[Orthodoxy] is such an old religion. It has held on to all those

3 When the women spoke of the traditionalism of Orthodoxy, they made use of an existing discourse within the Church. In the post-war context, the emphasis on the old age of Orthodox Christianity became one of the tactics with which Finnish Orthodox clergy countered challenges to the identity, beliefs, and practices of the Church (Kananen 2012, 47). 
[teachings] since the early times. (...) When the Lutheran Church turns two thousand years old too, it probably doesn't lose its [way] anymore. Like an old person, it gains life experience."

Moreover, when describing Orthodoxy, the interviewees often also remarked on the tone of Orthodox services, rituals, and other functions. Orthodox ritual life was mentioned to be "rich" and "multiform," the message of Orthodox services was depicted as "tolerant," "forgiving," and "bright," and the overall atmosphere in church functions was described as "unreserved" and "free." When making these kinds of assessments, the women underlined their argument by stressing how different the atmosphere was in the Lutheran Church. Lutheran services and rituals were seen to be "boring," "plain," "stiff," and "bleak," and the tone of Lutheran church functions "glum," "severe," and even "cruel." However, often the interviewees made sure to note that the Lutheran Church was no longer as strict as it had been during their youth. ${ }^{4}$

The interviewees also used comparisons when describing specific Orthodox customs and beliefs. One way of establishing a comparative perspective was to remark on what the Lutherans thought of a certain Orthodox practice. In this vein, the women reflected on Lutherans' (former) disapproval of certain Orthodox practices. For instance, they might note how, in post-war Finland, the Orthodox were sometimes called image-worshippers (kuvainpalvoja) due to them keeping and revering icons (see Kananen 2010, 73-76). Alternatively, it was also common for the informants to remark how, nowadays, also Lutherans did this or that: made the sign of the cross, kept icons, or prayed for the dead as part of their church services. ${ }^{5}$ For some of them, the reference to Lutherans "doing it too" functioned as an additional justification of a particular practice.

4 When speaking of the forgiving atmosphere of Orthodox services compared with the severity of Lutheran ones, the women were describing the message on the sinfulness of man communicated in these services. There are certainly differences between mainstream Lutheran and Orthodox interpretations of this topic (see e.g., Ware 1964, 224-229); however, the accounts also reflect the impact of Pietistic Revivalism on Finnish Lutheranism during the first half of the 2oth century. Revivalist teachings emphasize the wickedness and incompleteness of all human beings, and the importance of repentance and reform (Heininen and Heikkilä 1996, 170-176; Kääriäinen, Niemelä, and Ketola 2005, 50-53). In many of the areas where the Orthodox evacuees resettled, the presence of Revivalism was strong. Incidentally, one of the criticisms that the locals of these areas voiced against the Orthodox was that they lacked proper contrition and remorse: their Church's stance towards sinning, that is to say, was too lenient (Kananen 2010, 74-75).

5 During recent decades, the Evangelical Lutheran Church has taken up various practices that reflect its Catholic heritage and resemble those of the Orthodox Church (Kirkkohallitus 2009, 114-115; Laasonen 2011, 39-43). As a result, many customs that were, in the post-war period, seen as clearly non-Lutheran are no longer alien to Lutheran worship. 
Since Lutherans approved of it, it could not be wrong. These women, that is, seemed to feel a need to defend their customs when faced with a Lutheran interviewer. Others, in contrast, pointed out changes in Lutheran ways to demonstrate the superiority of Orthodox practices. To them, these changes were evidence of Lutherans finally recognizing the value of Orthodox customs.

My concern here does not lie in the actual differences between the two Churches. With the above discussion I have, instead, wanted to illustrate the contrast with Lutheranism that characterized the women's accounts about the nature of the Orthodox religion. When discussing Orthodoxy, the interviewees were prone to address themes which established a distinction with Lutheranism. Their accounts regarding these themes were, moreover, often more verbose than their other descriptions of Orthodoxy. For instance, they produced theological reflections mainly concerning issues where the interpretations of the two Churches differ, such as icons. All in all, the comparative perspective offered by the Lutheran Church facilitated the women's being able to distinguish and to reflect upon particular characteristics of Orthodox Christianity. It was with respect to Lutheranism that they were able to consider their own religion as, for example, traditional. In this way, their view of Orthodoxy was affected by Lutheranism always being the other side of the story.

In all likelihood, the women's comparisons were partly triggered by my Lutheran background. Living in a Lutheran society had made them competent translators of their Orthodoxy to Lutherans, and contrasting Orthodox practices with Lutheran ones often provided an easy translation. The interviewees could, for example, explain the sign of the cross to their Lutheran interviewer by noting, like Elvi, that "it is something... something that you use to bless. The same as Lutherans pressing their hands together." ${ }^{6}$ Nevertheless, such comparisons were not merely about adapting one's discourse to non-Orthodox ears. They also reflected the informants' more general tendency to view their religion in a comparative light. The women, I suggest, had come to comprehend some of their practices and beliefs in part through their contrast with Lutheran ones. They saw the practice of making the sign of the cross essentially also as something that differentiated the Orthodox from the Lutherans, that the Lutherans had recently commenced doing, and that corresponded in some ways with the Lutheran gesture denoting prayer. Therefore, reflecting on

6 When praying, Lutheran Finns press the palms of their hands together, with fingers bent and interlocked. This, however, is first and foremost a gesture of reverence and pleading. Thus, in the Small Catechism, Martin Luther (1529/1986, "Daily Prayers") distinguishes between "asking a blessing" with folded hands and "blessing" oneself with the sign of the cross. 
the differences between Orthodox Christianity and Evangelical Lutheranism came easily to the women. It was one of their practices of speaking and thinking about religion.

As the examples above show, the interviewees judged certain aspects of Lutheranism quite harshly. While making these judgments, some of the women became aware of their negative tone, and downplayed their criticism by emphasizing their overall respect for the Lutheran Church. Nevertheless, from a Bourdieuan perspective, the women's outspoken comments make for a good illustration of tastes as part of habitus. Bourdieu $(1984,56)$ writes:

Tastes $(. .$.$) are the practical affirmation of an inevitable difference. It is$ no accident that, when they have to be justified, they are asserted purely negatively, by the refusal of other tastes. In matters of taste, more than anywhere else, all determination is negation, and tastes are perhaps first and foremost distastes[.] (...) [E] ach taste feels itself to be natural - and so it almost is, being a habitus - which amounts to rejecting others as unnatural and therefore vicious.

Habitus is the product of the individual's internalization of social divisions. In practices guided by the habitus, including classifying practices like the comparisons above, the individual usually comes to reproduce these divisions (Bourdieu 1984, 170, 246-249, 466-469). In some sense, then, the interviewees' tastes regarding religion were essentially about aversion towards Lutheran tastes. They were about reinforcing the distinction between Orthodox and Lutherans, since this difference constituted the most important social division in the women's religious environment. In fact, in the course of the research, I, too, experienced the effects of this same juxtaposition. When analyzing the interviewees' comments, a part of me was strangely offended by them. I found myself silently praising, for instance, the austere beauty of Lutheran churches compared to the forbidding murkiness of Orthodox ones. That is, I became briefly involved in the struggles of the religious field: in the contest, between religious groups, for power to define legitimate religious taste (Bourdieu 1984, 479-481). To me, this reaction came as a surprise. I am, after all, a lapsed Lutheran with merely a cultural connection to the Church.

\section{Childhood Religion versus Conversion}

The displaced Karelian Orthodox women's religious environment also included other social divisions besides that between Orthodoxy and Lutheranism. 
One such division was brought about by the phenomenon of conversion from and to Orthodoxy. During the first post-war decades, conversion from Orthodoxy was not uncommon among evacuees. The most common reason for converting was marriage to a Lutheran (Kananen 2010, 199-202; Laitila 2009, 342). The frequency of the phenomenon also showed in the interviews, in the long lists of (mostly female) relatives, siblings, friends, and acquaintances who had converted to Lutheranism produced by the women. In addition, some informants recounted how their mothers-in-law had suggested in the early stages of the marriage that they convert, while others (including Faina, above) spontaneously stated that, had they been required to convert, they would not have gone through with the marriage at all.

Conversion was a theme that the women often took up of their own accord. They usually voiced a strictly negative attitude towards conversion as regarded themselves, declaring that conversion "had never crossed" their minds or that they had "never thought about" converting. Siiri, for example, stated: "I've been Orthodox the whole [time], I've never... Many people changed to Lutheranism after marrying, but it never crossed my mind. I've wanted to be Orthodox." With these kinds of expressions, the women put emphasis on how alien the thought of conversion was to them. Nevertheless, they often formulated their opinions in a way that took into account the fact that they personally knew people who had converted. In their anecdotes concerning conversion, they empathetically highlighted the overall plight of the Orthodox in post-war Finland.

When confronted with the topic of conversion, it was common for the informants to emphasize the inherent and non-negotiable nature of their religiosity. To do this, they turned to such corporeal metaphors as I discussed in the first section. Soja, for example, asserted: "My Orthodoxy has been sucked from mother's milk and it doesn't leave me. (...) In war-time, my cousins among others changed to Lutheranism when they got [married]. Well, I was married to a Lutheran, but it never crossed my mind that I'd change to Lutheranism." Otherwise, the women could also state, or imply, that they were against conversion because it was important to stay true to the religion that they had been baptized into and raised in. They might argue, for instance, that "everyone gets by with her own faith." In this way, the topic of conversion brought to light a crucial component of their overall conception of religion. To the interviewees religion was, ideally and properly, the childhood religion.

Interestingly, this notion of religion was also in evidence in the women's accounts concerning their family members' conversions to Orthodoxy. On the one hand, those interviewees with a child who had converted to Orthodoxy in adulthood usually indicated their satisfaction with this turn of events. On the other, only one woman explicitly stated her wish that her children would 
convert. Moreover, some women actually recounted their negative reactions to a family member expressing an interest in converting. In this vein, Katri stated: "My husband was interested [in Orthodoxy], and suggested many times that we transfer our whole family into the Orthodox Church. But (...) I said that everyone can take care of that thing themselves. If someone wants to change his religion voluntarily, he can do that. But I don't [insist on it]." Katri, that is, did not view even her own family's conversion to Orthodoxy as a necessarily positive thing.

In the last quarter of the 2oth century, the trends of conversion within the Finnish Orthodox community changed course. Simultaneously as the amount of conversions from Orthodoxy started to diminish, the number of conversions to Orthodoxy rose. According to Orthodox theologian Riina Nguyen (2007, 123-124), since then some tension has occasionally arisen within the community between converts and those baptized into Orthodoxy as infants. Also the interviewees considered the issue of converts versus "native Orthodox" a sensitive topic. It was common for them to make note of the increasing number of converts in the Church; however, whereas some spontaneously remarked on the religiosity of converts, others declined to answer even my direct question concerning the topic. The women could also emphasize that they were speaking of converts "with love," adding that the converts they personally knew were wonderful people.

Faina: I'd almost say that they are holier than we are. For us, it's all so innate. It has been given to us in our mother's milk. And they have studied it in a whole other way, from books and from examples and such. Yes, their bows are deeper and signs of the cross more devout. When you watch them at church. And for sure they don't come there in trousers like I do, but they have skirts. And black clothes. It's not part of Karelianness to wear black clothes.

Here, Faina recounts her experiences concerning the behavior of converts at church. She makes an observation that recurred in many interviews: converts seemed more pious than people who had been raised to Orthodox Christianity. The women, that is to say, often described converts as more serious about religion, and stricter when it came to the observance of Orthodox customs. In addition, they could find converts to be less tolerant of difference than those socialized to Orthodoxy as children who, in their opinion, were more flexible and humble. Furthermore, Faina's description also identifies the behavior of converts, at least when it comes to the color of their church attire, as nonKarelian. Indeed, one major difference between converts and the women was 
that the former did not necessarily express an interest in Karelian customs even though a significant number of recent converts to Orthodoxy do have some kind of Karelian heritage (Martikainen and Laitila 2014, 172).

When speaking of converts, the interviewees also described conversion to Orthodoxy as an arduous process requiring much work and study. They noted how converts were often quite learned about the Orthodox religion, which was admirable. At the same time, they could reproach converts for their tendency to advise others on Orthodox doctrine and cult based on their studies. Moreover, the women also openly spoke of the limits of "book wisdom" and "abstract knowledge" concerning religion. They were quite skeptical towards the idea that one could ever form the right kind of emotional bond with religion through conscious effort. With these reflections, they expressed their view that religion should, ideally, be acquired during childhood, and not learned from books later on. ${ }^{7}$

According to Bourdieu, the major difference between primary and secondary socialization is that primary socialization always originally results in doxa (Bourdieu 199ob, 67; see also Berger and Luckmann 1971, 136-141). Because the child learns simultaneously to act and to think in the ways of a particular culture, he or she remains unaware of all that is tacitly granted within that culture. In secondary socialization, however, the foreign culture is perceived through an already constituted disposition. It is seen as an arbitrary construct; moreover, it is usually expressly studied. These differences are also evident in the interviewees' reflections describing the religion of converts.

The women's accounts present those who were natives to Orthodox culture as not very strict about the observance of practices. As one informant explained, practice came to them "from within"; in other words, it flowed from their sense of practice. The interviewees' emphasis on the rule-orientation of converts to Orthodoxy, in contrast, suggests that what especially caught their attention were relatively recent converts who were still undergoing a process of re-habituation. Lacking the proper dispositions, these converts were dependent on abstract principles and rules. In the course of time and through emotional commitment, it is possible also for cultures adopted through secondary socialization to become routinized and embodied, governed more by habit than by conscious adherence to rules (Berger and Luckmann 1971, 176-182).

7 Many of the women, nevertheless, had at some point during their adult lives studied Orthodoxy. Maija-Liisa, whose childhood home had not been fully Orthodox, spoke at length of her quest to learn of her "Orthodox roots." The women who had not had the possibility of attending Orthodox religion classes at school, moreover, commonly mentioned how they had later amended this gap in their education by reading on the Orthodox religion. 
After reaching this point, the behavior of converts would probably no longer attract the women's attention to the same extent.

Finally, a particularly interesting aspect of the informants' accounts addressing the phenomenon of conversion is how they came to characterize their own religion when confronted with the issue. In the contrasting light created by the phenomenon, they were able to reflect on their religion as a particular type of religion: religion into which one has been socialized as a child. Early on in this chapter, I examined the interviewees' accounts of their childhood religion as evidence of their actual experiences pertaining to the native layer of their habitus. That they produced some of these accounts as part of their reflections concerning conversion does not undermine the validity of the analysis. The accounts discussed here suggest that the existence of alternatives had indeed made the women, to some extent, aware of the native layer of their habitus and of their doxic relationship towards religion. However, the accounts also show how their childhood experiences continued to function as the foundation of their religious tastes, and their classifications concerning proper religion.

In Bourdieuan theory, the existence of practical belief is a prerequisite for participation in any field (Deer 2008a, 121). However, as Mustafa Emirbayer and Ann Mische $(1998,973)$ note, reflective tendencies can fluctuate in either direction as a result of the increasing problematization or routinization of experience. The Orthodox women's capacities for actively reflecting on their religion, my material suggests, were activated particularly in environments in which they came face to face with different religiosities and ways of life. All in all, their ability to engage with religion with varying levels of awareness speaks of the layered composition of their habitus (see also Bender 2012, 284-288).

\section{Childhood Religion, Pluralistic Setting, and Agency}

I conceptualize agency as a product of habitus and a built-in feature of all action (see Emirbayer and Mische 1998, 976, 1004; McNay 2000, 23, 40, 46-47). In this and the previous chapter, I have analyzed the evacuee Karelian Orthodox women's interview accounts for information on the formation of their habitus, and on the outcome of this formation as reflected in their present-day religious activity. Below, I shall identify some of the agentic capacities entailed in the dispositions I have uncovered thus far.

In her research on the life-world of elderly North Karelian women, MarjaLiisa Honkasalo (2015, 69; 2009, 61-64; 2008b, 83-85, 207-210) calls attention to agency embedded in habitual everyday practice. By the term "small agency," she refers to agency as it is realized in women's everyday activities: cooking, 
cleaning, gardening, doing handicrafts, socializing with neighbors, and so on. Relying, for instance, on Pierre Bourdieu and the anthropologist Ernesto di Martino, Honkasalo (2008b, 207-210, 216; see also 2015, 70-73) views routine practices as constitutive of basic ontological security. Routinization establishes stable spatiotemporalities which are experienced as protective and safe. In this sense, routine action is crucially important in the life of every individual.

Honkasalo's conceptualization of small agency also provides an incisive interpretation of the everyday religious activities of the women in my research. With their daily, small-scale religious practices, the interviewees achieved quite significant things with respect to their lives as a whole. They constituted an everyday domestic environment in which religion was continually present. Furthermore, the observation of simple and private customs such as praying was one aspect of their religion that had been preserved more or less intact throughout their lives. Although none of them followed childhood practices to the letter, they had been able to adapt at least some of these customs to their different life situations. The practices established continuums with respect to the past, forming layers upon layers of reiterated tradition. To the women, they connoted stability, continuity, predictability, and security in a most potent manner (see also Honkasalo 2015, 77-81).

In her account of agency, Honkasalo (2008b, 212-213) emphasizes that routine action also forms the foundation for more creative activities. One way to view routines as conducive to innovation is through a focus on how the habitus is imbued with capacities for action that are transferrable between contexts.

Helena: What was that trip (to visit her childhood home in present-day Russian Karelia) like then?

Hilja: Well, since I'm a spiritual person, it meant a great deal to me. I had wax candles with me and I put them and burned them at that corner where we had an icon. (...) All the other villagers wondered how I came up with that. I said to them that this is no invention. This is part of our life, the Orthodox life. To have candles with you when you visit those childhood places and the ruins of your home. I burned those candles there at the ruins. Like... in the memory of my parents and of the home.

In this excerpt, Hilja describes how, when she was on her first visit to her family's pre-war home area in present-day Russia, she performed a small ritual of remembering by lighting candles at the ruins of her childhood home. ${ }^{8}$

8 These trips became popular after the fall of the Soviet Union, when travelling to Russia became easier (see e.g., Fingerroos 2006). 
The account is a good example of how habitus, as the effect of past action, generates future capacities for action. For Hilja, it had come naturally to burn candles in the icon-corner of the ruins of her childhood home. For the cotravelers questioning Hilja about her actions, it obviously had not occurred to do the same. I maintain that Hilja's capacity to perform this makeshift ritual stemmed from her active, habitual Orthodox practice which included ritual occasions for the remembering of ancestors and the burning of wax candles in front of icons to mark special occasions. For her, the ritual was daily religiosity, only brought to another environment. Ultimately, Hilja's narrative is an account of the living-through of her pre-formed capacities for action in a particular, singular situation. As such, it fully demonstrates the agentic dimension of routine action.

Besides taken-for-granted routines, the interviewees' everyday religion also included more conscious elements, practices that were about the claiming and acting out of their religious identities (see Leming 2007, 74). I approach the agentic capacities realized in these activities through anthropologist Orit Avishai's description of agency. For Avishai $(2008,413)$, religious agency is realized in the observance of religious customs. Relying, for instance, on Judith Butler and Saba Mahmood, she speaks of the doing of religion as a "semiconscious, self-authoring project," as well as a "mode of conduct and being, a performance of identity." Avishai (2008, 423, 427-428) implies that the semiconscious nature of "doing religion" is due to the heterogeneity of the surrounding social world. From her own research on the purity rituals of Israeli Orthodox Jewish women, she extracts the idea that religious agency can be pitted against the image of the secular other.

Avishai's conceptualization of religious agency as an activity in which religiosity is semi-consciously performed against cultural others fits well with the case of the Orthodox women. The comparisons that the interviewees were in the habit of making are one example of the ways in which this modality of religious practice surfaced in the interview situations. Moreover, against a backdrop of religious pluralism even routine religious customs can become problematized and more of a conscious enterprise, a project of affirming one's cultural self which is experienced as being under threat (see also Orsi 2010, 195; Ortner 2006, 147; Snajdr 2005, 306).

On the basis of interview material, it is hard to say to what extent the women, while conducting their religious routines, were also performing their Orthodoxy, practicing it in relation to others. Naturally, this aspect of their religiosity became operative when they were face to face with those representing an alternative way of doing religion. In these situations, their religious activities could become identity statements of, for instance, their Orthodoxy or their childhood religion. However, I am inclined to think that at least in some cases 
the established Orthodoxy of a practice, or its established childhood connection, was important to them also on a personal level.

Siiri: To end my evening prayer, I always recite: "Surround me, O Lord, with the power of your honorable and life-giving cross, and preserve me from every evil." And I find it so well put, the "with the power of your lifegiving cross!" I've said this prayer for a long time ... I know a lot of evening prayers, but this is one that is connected with Orthodoxy specifically.

In the account above, Siiri speaks of her habitual evening prayer, noting that the particular prayer with which she ends her session reminds her of Orthodox Christianity. Indeed, the prayer in question is recommended as an evening prayer in the Orthodox prayer book (McGuckin 2008, 346; Nyström 2001, 12). Siiri belongs to the majority of my informants who have lived their adult lives as the only Orthodox members of otherwise Lutheran nuclear families. Thus, it is not hard to imagine her evening prayer as a routinized practice through which she connected herself with the Orthodox community. Her evening prayer, in other words, was not just a practice of establishing communication with God; it was also a way of re-establishing her Orthodox identity.

I consider Siiri's account one small example of how the women could direct also their routine religious performances against cultural others. Through their practices of thinking and speaking of as well as doing religion, the women secured their place and position in the social world, reinforcing their ties with particular communities and cultivating a sense of belonging. This is something that happens, to some extent, with all kinds of action. However, the process inevitably gains intensity in highly pluralistic or minority contexts. Overall, I regard this semi-conscious, performative aspect of the women's religious practice as the central agentic capacity brought on by the minority layer of their habitus.

Based on her research, Avishai $(2008,422-423,428)$ views religiosity as a continuous project of "becoming" an authentic religious subject through practice. When doing religion, the Orthodox Jewish women of Avishai's study both separated themselves from the secular other and aspired to religious ideals, although never fully attaining them. For the women of my study, such becoming, as an intentional project of cultivating one's subjectivity through pious conduct, was not central to the same extent. Nevertheless, the interviewees did sometimes also reflect on their religiosity with respect to their ideals of Orthodox Christian practice, and not only with respect to religiously different others. One such ideal consisted of the "living" of religion. This idiom, which I 
have interpreted as a reference to a thoroughly doxic relation towards religion, captured the women's take on the essence of proper Orthodox practice.

In addition to constituting an expression of the women's religious tastes, the notion "to live religion" is also indicative of their perspective on the particular challenges that their present-day surroundings posed to religious observance. In a pluralistic environment, the capacities of distinguishing between and reflecting on discourses, as well as affiliating with and distancing from them, become crucial to any individual. In the wake of these capacities, however, the individual's relationship towards the social world is unavoidably changed. This was also the case with the displaced Karelian Orthodox women. The surrounding religious heterodoxy had seeped into their habitus, turning into an awareness of their religious activities as only one possibility among others. Such knowledge can become a taken-for-granted part of practices - leading to routinized reflections, performances, and the like. Nonetheless, it often rules out the possibility for actually "living" religion. In the least, harboring a thoroughly doxic relation towards religion becomes an ideal that is much harder to attain. 